\title{
Indemnity Clauses and Workers' Compensation: A Proposal for Preserving the Employer's Limited Liability
}

Under the California workers' compensation system, ${ }^{1}$ an employee mjured on the job is compensated by the employer regardless of the employer's responsibility for the mjury. ${ }^{2}$ The amount of compensation is dictated by statute, ${ }^{3}$ and the employee is prohibited from pursuing any additional recovery against the employer. The workers' compensation system thus benefits both the einployee and the einployer; by avoiding the expense, delays, and uncertamties of litigation, the system guarantees the employee a swift and certain recovery and limits the extent of the employer's liability.

While the California workers' compensation system limits an employer's liability to the employee, it expressly preserves an employee's right to recover full tort damages from a third-party tortfeasor. ${ }^{4}$ This right, in conjunction with the rule of jomt and several liability for multiple tortfeasors, may result in a negligent third-party tortfeasor being held liable to an imjured employee in an amount beyond the third party's comparative responsibility for the employee's imjury.

Where possible, third parties may seek to avoid this risk of liability to employees through contractual indemnification clauses which require the employer to reimburse the third party for any such liability it may mcur. While these clauses do protect third parties, they create an additional loss allocation problem, as they result in an employer being responsible for the full tort recovery of its employee: a result in direct conflict with the workers' compensation sclieme.

This Comnient examnies this conflict in the context of the construction industry. Part I provides background on the California workers' compensation system and the employee's right to seek a full recovery agamst third-party tortfeasors. Part II explaims low indemnification clauses shift the third party's liability to the employer, in con-

1. See CAL. Lab. Code $\$ 3600$ (West Supp. 1982).

2. For the few exceptions to the exclusive and limited aspects of workers' compensation, applicable to those cases in which the enployer's actions are especially egregious, see generally Note, Johns-Manville Products Corp. v. Superior Court: Intentional Aggravation of Injury as an Exception to Exclusive Workers' Compensation Remedies, 69 CALIF. L. REv. 1230 (1981).

3. See generally CAL. LAB. CODE $\$ \S 4550-4554$ (West 1971):

4. Id. $\$ 3852$ (West Supp. 1982). 
tradiction to the design of the workers' compensation system, and argues that insurance does not resolve this contradiction. Part III describes how Congress has addressed a similar problem in the maritime area by prohibiting indemnity claims against the employer. Part IV proposes a modified version of the federal approach for the California construction industry. It recommends prohibiting clauses indemnifying the third party, limiting third-party liability to its percentage of comparative fault, and prohibiting subrogation liens by the employer on the employee's tort recovery. The proposal is consonant with the purpose of the workers' compensation system, and will elimmate duplicative insurance costs and litigation expenses that are prevalent under the current system.

\section{I \\ COMPENSATION FOR INJURED EMPLOYEES}

This Part describes the California workers' compensation system and its preservation of the employee's right to sue third-party tortfeasors.

\section{A. Recovery from the Employer: Workers' Compensation}

California Labor Code sections 3600 and 3601 set out the funda: mental elements of the California workers' compensation system. Section 3600 provides that the employer shall be liable for injuries suffered in the course of employment without regard to the employer's negligence. ${ }^{5}$ Section 3601 adds that recovery of compensation under section

5. Id. $\& 3600$. Section 3600 provides that:

Liability for the compensation provided by this division, in lieu of any other liability whatsoever to any person except as provided in Section 3706, shall, without regard to negligence, exist against an employer for any injury sustained by his employees arising out of and in the course of the employment and for the death of any employee if the injury proximately causes death, in those cases where the following conditions of compensation concur:

(a) Where, at the time of the imjury, both the employer and the employee are subject to the compensation provisions of this division.

(b) Where, at the time of the injury, the employee is performing service growing out of and incidental to his employment and is acting within the course of his employment.

(c) Where the injury is proximately caused by the employment, eithcr with or without negligence.

(d) Where the injury is not caused by the intoxication of the injured employee.

(e) Where the mjury is not intentionally self-inflicted.

(f) Where the employee has not willfully and deliberately caused his own death.

(g) Where the injury does not arise out of an altercation im which the injured employee is the initial physical aggressor.

(h) Where the injury does not arise out of voluntary participation in any off-duty recreational, social, or athletic activity not constituting part of the employee's work-related duties, except where such activities are a reasonable expectancy of, or are expressly or impliedly required by, the employment. The admimistrative director shall promulgate reasonable rules and regulations requiring einployers to post and keep posted in a con- 
3600 is the employee's exclusive remedy against the einployer. ${ }^{6}$

Sections 3600 and 3601 are substantive declarations limiting the employee's claim against his employer to those benefits provided by the compensation law and foreclosing entitleinent to the damages otherwise available through legal action. ${ }^{7}$ The workers' compensation system thus limits the liability of the einployer while guaranteeing recovery for the einployee regardless of employer fault and despite any defenses which the einployer might otherwise plead. ${ }^{8}$

The workers' compensation systein is in part recognized as a bargain, a quid pro quo, reached between einployers and einployees for their mutual benefit." The system has also been viewed as "an unmis-

spicuous place or places a notice advising employees of the provisions of this subdivision. Failure of the employer to post such a notice shall not constitute an expression of intent to waive the provisions of this subdivision.

See also CAL. ConsT. art. XIV, $\$ 4$ (enabling the enacunent of a coinprehensive workers' compensation system). Some $87 \%$ of the national work force is covered by a workers' compensation system. J. Chelius, Workplace Safety and Health: The Role of Workers' Compensation 20 (1977). For an interesting history of the statutory inovement toward workers' compensation, see Tarpley \& Jagmin, Worker's Compensation: Third Party Actions Against Employers Under Comparative Causation, 47 J. Air L. \& CoM. 187, 194-203 (1982).

6. Cal. LAB. CODE $\S 3601$ (West Supp. 1982). Section 3601 provides that:

(a) Where the conditions of compensation exist, the right to recover such compensation, pursuant to the provisions of this division is, except as provided in Section 3706, the exclusive remedy for injury or death of an employee against the employer or against any other employee of the employer acting within the scope of his einployment, except that an employee, or his dependents in the event of his death, shall, in addition to the right to compensation against the employer, have a right to bring an action at law for damages against such other employee, as if this division did not apply, in either of the following cases:

(1) When the injury or death is proximately caused by the willful and unprovoked physical act of aggression of such other employee.

(2) When the injury or death is proximately caused by the intoxication of such other employee.

(b) An act which will not sustain an independent action for damages against such other employee under paragraph (1) or (2) of subdivision (a) of this section may nevertheless be the basis of a finding of serious and willful misconduct under Section 4553 or 4553.1, if (1) such other employee is established to be one through whom the einployer may be charged under Section 4553; (2) such act of such other employee shall be estabhished to have been the proximate cause of the injury or death; and (3) such act is established to have been of a nature, kind, and degree sufficient to support a finding of serious and willful misconduct under Section 4553 or 4553.1 .

(c) In no event, either by legal action or by agreement whether entered into by such other employee or on his behalf, shall the employer be held liable, directly or indirectly, for damages awarded against, or for a liabihty incurred by such other employee under paragraph (1) or (2) of subdivision (a) of this section.

(d) No employee shall be held liable, directly or indirectly, to his employer, for injury or death of a coemployee except where the injured einployee or his dependents obtain a recovery under subdivision (a) of this section.

$B u t c f$. Note, supra note 2 (outlining the intentionally egregious actions exception to the exclusivity of workers' compeusation).

7. E.g., Azevedo v. Abel, 264 Cal. App. 2d 451, 454, 70 Cal. Rptr. 710, 712 (3d Dist. 1968).

8. See Alameda Tank Co. v. Starkist Foods, Inc, 103 Cal. App. 3d 428, 432, 162 Cal. Rptr. 924, 926 (2d Dist. 1980); see generally J. Chelius, supra note 5, at 27.

9. See, e.g., Epstein, Coordination of Workers' Compensation Benefits with Tort Damage Awards, 13 ForUM 464, 468-69 (1978). 
takable declaration of legislative policy that the cost of industrial injury, at a scale fixed by the compensation law, shall be borne by the employing enterprise."10 The modern compensation system is probably best viewed as a product of a coinbination of these forces; that is, the legislature intended to ensure that injured employees were compensated, and it worked witl employers and employees to devise a system that accommodates their competing interests. Thus, the system is solidly based upon both a bargained-for exchange between the parties involved and a declaration of legislative policy.

Workers' compensation benefits are governed by statute and generally include medical expenses, partial compensation for lost wages, and payments for temporary or permanent disabilities. ${ }^{11}$ Because of the strict liability aspect of workers' compensation, as opposed to the negligence standard that generally governs mjuries to employees in tort law, compensation benefits may exceed what the employee would recover at common law. However, where the employee would have a legal claim against a negligent employer but for the exclusivity of the compensation system, the statutory scheme often results in a recovery significantly smaller than the potential tort recovery or the actual loss sustained by the employee. ${ }^{12}$

\section{B. Recovery from Third-Party Tortfeasors}

Although the workers' compensation system applies to all injuries sustaimed by an employee in connection with his job, its scope is limited to claims against the employer. In many instances, however, the employee's mjury results from the exclusive or concurrent fault of a third party. In such cases, the Labor Code preserves the employee's right to

10. Pacific Gas \& Elec. Co. v. Morse, 6 Cal. App. 3d 707, 714, 86 Cal. Rptr. 7, 11 (3d Dist. 1970).

11. See CAl. LAB. CoDE $\$ \S 4451-4754$ (West 1971 \& Supp. 1982).

12. Consider, for example, Edge v. Stapleton, No. 119403 (Cal. Riverside County Super. Ct. Sept. 4, 1980), summarized in 24 Jury Verdicts Weekly, Oct. 3, 1980, at 12. The plaintiff incurred medical expenses of $\$ 13,000$ and lost wages of $\$ 17,000$. There was no claim of permanent, partial, or total disability. The jury awardcd $\$ 175,000$, reduced by the plaintiffs $35 \%$ comparative fault for a net recovery of $\$ 113,750$. Under workers' compensation, such an injury would have resulted in a recovery of the full medical expenses and only part of the lost wages: an amount totaling less than $\$ 30,000$. Though such results depend on particular facts, the case is illustrative of the frequent differential between workers' coinpensation and tort awards.

See also Castro v. State, 114 Cal. App. 3d 503, 515, 170 Cal. Rptr. 734, 741 (4th Dist. 1981) ("It is common knowledge that workmen injured or killed in construction work do not receive full compensation under the Workmen's Compensation Act for daunages that they sustain. . . .) (quoting Widman v. Rossmoor Sanitation, Inc., 19 Cal. App. 3d 734, 747, 97 Cal. Rptr. 52, 59 (4th Dist. 1971)). But see Johns-Manville Products Corp. v. Superior Court, 27 Cal. 3d 465, 474, 612 P.2d 948, 955, 165 Cal. Rptr. 858, 865 (1980); Magliulo v. Superior Court, 47 Cal. App. 3d 760, 778-79, 121 Cal. Rptr. 621, 635-36 (1st Dist. 1975) (permitting an employee to avoid the workers' compensation restrictions for injuries intentionally inflicted by the employer). 
sue the third party in tort. ${ }^{13}$

The frequent discrepancy between workers' compensation benefits and potential tort awards naturally gives the einployee an incentive to find a third-party defendant against whom the larger award can be obtained, and employees have in fact been quite successful in doing so. ${ }^{14}$ As one commentator has stated, "Enterprising plaintiffs and accommodating courts have frequently managed to circumvent the operation of an immunity doctrine by finding a nonimmune third-party 'tortfeasor,' whose liability is often tenuous, vicarious, or legally fictitious." 15

This proliferation of employee tort claims is most apparent in suits by employees against those who hire their einployers. The duties of such third parties have been expanded by such concepts as the peculiar risk doctrine and the duty to exercise reasonable care over the manner in which the work is perforned. ${ }^{16}$ Increasingly, these third parties who hire independent contractors have also become subject to liability for the neghigence of otliers on the jobsite as well as for their own negligent acts or omissions. ${ }^{17}$ The result has been a plethora of einployee suits against third parties.

For several reasons, such employee suits against third parties have become particularly common in the construction industry. First, doctrines of third-party liability, such as failure to provide a safe place to work, ${ }^{18}$ are particularly applicable to the context of a construction jobsite where dangers abound. Second, construction sites are work places shared by unany parties, most of whom are not immune from suit under the conipensation laws. Often, on a construction site, several subcontractors are present, as well as a general contractor and a property owner; each is potentially liable for jobsite injuries to employees. The presence of several potential defendants niakes available additional theories of liability and increases the possibility of a tort recovery. As a result, the nultiple defendant situation increases the likelihood of a claim being brought. ${ }^{19}$

13. See Cal. Lab. Code $\$ 3852$ (West Supp. 1982).

14. See generally J. CHelius, supra note 5 , at 27.

15. Pulliam, Comparative Loss Allocation and the Rights and Liabilities of Third Parties Against an Immune Employer: A Modest Proposal, 31 FED'N INs. Couns. Q. 80, 80 (1980) (footnote omitted). 1981).

16. See, e.g., Castro v. State, 114 Cal. App. 3d 503, 509-16, 170 Cal. Rptr. 737-42 (4th Dist.

17. Id. at 509-10, 514, 170 Cal. Rptr. at 737-38, 740.

18. See id. at 517-18, 170 Cal. Rptr. at 742-43.

19. For example, where only the employer is present and in control of the jobsite, statutory benefits will be exclusive. When additional parties are present, the likelihood that a tortfeasor will be found and thus that a party other than the employer will be liable for the injury increases. In such situations, workers' compensation is no longer the exclusive remedy. Concomitantly, the funds potentially available to compensate the employee are also likely to increase. Thus, the 
II

\section{The Problems Presented}

\section{A. Contractual Indemnification v. Workers' Compensation}

Not only does the construction site present an expanded opportumity for einployee tort suits, it also raises the problem of coordinatimg the relative rights of the employee, the employer and the third-party defendant once work-related tort claims are brought. This problem is intensified by the operation of contractual indemnity clauses typically contained in construction contracts. ${ }^{20}$ Such clauses usually require the subcontractor to indemnify the general contractor for any liability the general contractor may incur as a result of the subcontractor's performance of the contract. ${ }^{21}$

When such indemnity clauses are applied to employee suits against general contractors, they substantially threaten the successful operation of the workers' compensation systein. As mentioned earlier, the system was designed to provide guaranteed benefits to the employee regardless of einployer fault and, in exchange, guaranteed limited liability for the employer. Labor Code section 3852, allowing suits by employees against negligent third parties, does not itself change the quid pro quo of the compensation system: it merely creates the potential for additional employee recovery against parties other than the enployer. However, if the employer is a subcontractor bound by contract to indemnify a general contractor for any liability the general inay face as a defendant in the employee's action, the quid pro quo is destroyed because the indemnity clause undermines the employer's protection against unlimited liability. In this situation, contractual mdemnity effectively inakes the einployer liable im tort to its own einployee for

greater the number of potential defendants, the greater the likelihood that potential claims in addition to workers' compensation will be pursued.

20. See Annot., 68 A.L.R.3d 7, 22 (1976).

21. A typical indemnity clause is contamed in Article 11.11 of the American Institute of Architects' standard form subcontract, as reprinted in R. Cushman, M. SIMON \& M. STOKEs, CONSTRUCTION INDUSTRY FORMBOOK 218-19 (1979):

11.11.1 To the fullest extent permitted by law, the Subcontractor shall indemnify and hold harmless the Owner, the Architect and the Contractor and all of their agents and employees from and against all claims, damages, losses and expenses including but not limited to attorney's fees, arising out of or resulting from the perfornance of the Subcontractor's Work under this Subcontract, provided that any such claim, damage, loss, or expense is attributable to bodily injury, sickness, disease, or death, or to injury to or destruction of tangible property (other than the Work itself) imcluding the loss of use resulting therefrom, to the extent caused in whole or in part by any negligent act or omission of the Subcontractor or anyone directly employed by him or anyone for whose acts he may be liable, regardless of whether it is caused in part by a party indemnified hereunder. Such obhgation shall not be construed to negate, or abridge, or otherwise reduce any other right or obhgation of indemnity which would otherwise exist as to any party or person described in this Paragraph 11.11. 
damages sustamed in connection with the employinent-a result the workers' compensation systein seeks to avoid.

Such a situation is common under California $\mathrm{law}^{22}$ and is illustrated by Gonzales v. R.J. Novick Construction Company. ${ }^{23}$ In that case, the plaintiff, Gonzales, was a brick tender employed by Vienna Stone Company, a subcontractor hired by the defendant general contractor, Novick. The subcontract contamed an indemnity provision. When Gonzales brought suit agamst Novick for work-related mjuries, Novick sought to enforce the imdemnity provision against Vienna. After considering the limitations imposed by Labor Code section $3864^{24}$ and Civil Code section $2782^{25}$ upon such indemnity provisions, the Califorina Supreine Court concluded that the imdemnity provision was valid and enforceable. As a result, despite the workers' coinpensation provisions and despite Novick's neghgence, Vienna was liable for $100 \%$ of its own employee's tort recovery.

As Novick Construction demonstrates, enforcement of an indemmity clause against a subcontractor whose employee sues a neghigent general contractor completely circumvents the workers' coinpensation system. The employee benefits froin the existence of a third party who is not protected from tort liability. Moreover, the einployee inay benefit from a less than ardent defense by a general contractor who inay actually have nothing at risk. The general contractor, a nominal defendant, need only avoid a determination that it is the sole negligent party; in all other cases, the imdemnity clause will protect the general from any loss. ${ }^{26}$ Therefore, it is actually to the general contractor's advantage to show that the subcontractor-einployer was partially negligent, thereby assuring indemnity protection. Thus, as the general contractor defends its best interests, it may indirectly increase the liability of the subcontractor. At the least, the general contractor may be mdifferent to the defense of the claim where it is apparent that there is concurrent neghigence of additional parties. As a consequence, the einployer is forced to bear the burdens of defense and ultimate tort liability-the precise burdens of which the legislature intended to relieve it.

22. J. SweEt, Legal Aspects of ARchitecture, EngINeERing and the Construction Process 752-53 (2d ed. 1977).

23. 20 Cal. 3d 798, 575 P.2d 1190, 144 Cal. Rptr. 408 (1978).

24. CAL. LAB. CoDE $\S 3864$ (West 1981) provides that indemnity can only be created by express agreement; see infra text accompanying notes 54-55.

25. CAL. Civ. CoDE $\$ 2782$ (West Supp. 1982) provides that parties to a construction contract cannot contract for indemnification of liability arising solely from their own negligence; see infra text accompanying note 69.

26. See infra notes $68-69$ and acconpanying text. 


\section{B. Insurance: an Inadequate Solution}

Courts $^{27}$ and commentators ${ }^{28}$ often minimize the problem presented, arguing that the availability of insurance reduces the issue to an inconsequential question of which party must bear the burden of insuring against the risk. However, insurance does not solve the problem; rather, insurance itself presents a major argument for change in third-party suits involving indemnification.

The entire workers' compensation system is an msurance scheme designed by the interested parties and the legislature to provide adequate coverage against the risks of employment at mimimum cost to the parties. Moreover, the bargaining process that led to the workers' compensation system created a balanced compromise: limited but certaim payments for work-related injuries. To the extent that the legislature was successful in striking an efficient and equitable balance, it must be recognized that interference by indemnity contracts with the normal operation of the compensation system produces inefficient and mequitable results.

The most obvious inefficiency resulting from indemnity contracts is the need for multiple insurance pohicies against a single risk. Although indemnity requirements could conceivably be used to put the entire risk on the party who can insure at lowest cost and thereby mimimize the overall cost to the enterprise, in reality such requirements do not have this effect. The indemnity provision forces the subcontractor to insure against the risk but does not thereby obviate the need for imsurance agamst the same risk by the general contractor or the owner. The result is that several different parties have to purchase insurance for the same underlying risk. ${ }^{29}$

Of course, since the premiums that insurance companies charge are based in large part on the amount that they expect to pay out in claims, if the total claim amount for injured parties does not rise, then total premiums should rise only by the amount of increased admimstrative costs. In that case, the premiums paid by the subcontractor and the general together would be inore than that paid if only one party were responsible for the whole risk, but only by the amount of these administrative costs plus the insurer's profit-not imsubstantial amounts in themselves. To the extent the insurance market is not completely efficient, there will be additional costs associated with duplicate

27. Guy F. Atkinson Co. v. Schatz, 102 Cal. App. 3d 351, 356, 161 Cal. Rptr. 436, 438-39 (1st Dist. 1980); John E. Branagh \& Sons v. Witcosky, 242 Cal. App. 2d 835, 838-39, 844, 51 Cal. Rptr. 844, 846-47, 850 (1st Dist. 1966).

28. Pulliam, supra note 15 , at 83; J. SwEET, supra note 22, at 753-54.

29. E.g., Hermen Christensen \& Sons, Inc., v. Paris Plastering Co., 61 Cal. App. 3d 237, 24647, 132 Cal. Rptr. 86, 91 (1st Dist. 1976). 
coverage. In sum, rather than reducing overall insurance costs, indemnity provisions increase the total cost of insuring a construction project.

The mcreased insurance burden on the employer also thwarts the built-in incentive structure of the tort system. ${ }^{30}$ If a general contractor directly bears the burden for the results of its own negligence, a repeatedly neghigent general will have to pay increased insurance premiunis and will be less able to compete with other, safer contractors as its insurance costs rise. However, if the general contractor is continually able to contract out of responsibility for its own negligence, neither its insurance costs nor its profits will refiect its poor safety record, and it will, as a result, have little incentive to increase the safety of its operations. ${ }^{31}$ The subcontractor, on the other liand, will repeatedly be exposed to hability, at least in part for the negligence of others. Its apparently poor safety record will increase its insurance preıniums. These higher costs may reduce its capacity for competitive bidding and thus dimimish its ability to compete in the market. Thus, the impact of the indemnity requirement on insurance may be to punish relatively safe einployers for the negligence of general contractors who are not being policed by the economic consequences of their unsafe operations.

The burden of double insurance associated with contractual indemnity also leads to wasteful duplication of litigation expenses. When an injured einployee brings suit, the general contractor's carrier inust assune the defense, because the general retains some potential for liability. ${ }^{32}$ The general will of course raise the indemnity issue, bringing

30. For the "social engineering" incentive structure in the torts system, see generally W. Prosser, The Law of TorTs $\S 3$, at 14-16 (4th ed. 1971).

31. It might be argued that general contractors with bad loss records would in fact bear the burden of the loss in the form of higher bids from subcontractors. That is, subcontractors could pass back to general contractors the cost of their increased exposure resulting from a careless general contractor. However, this argument has several flaws.

First of all, the subcontractor is generally not in such a powerful bargaining position vis-a-vis a general contractor. See infra notes 58-70 and accompanying text. Thus, in the competitive construction contracting market, the subcontractor inay not actually have the power to pass on these costs.

Second, relieving the general contractor of hability for his negligence removes the economic signals that would otherwise serve to notify other parties of the contractor's poor record. While insurance companies will be well aware of an insured's loss record and will adjust his premiums accordingly, when a contractor is able to avoid the consequences of his loss record, subcontractors who deal only by chance with the contractor will probably lack the full information necessary to incorporate the increased exposure into the cost of the contract. Rather, it is the subcontractor who may later suffer increased insurance costs arising from a loss which was caused partly or wholly through the fault of the general contractor.

32. See infra text accompanying notes $69-70$, explaining that indemnity is not available where the general contractor is found to be the sole neghigent party. Moreover, the typical indemnity agreement requires the subcontractor not to assume the general contractor's defense, but merely to indemnify. See supra note 21; but see CAL. Clv. CoDE \$ 2778(3)-(4) (West 1974), requiring the imdemnitor to reimburse the indemnitee for the cost of defending the action and to undertake the indemnitee's defense if the indemnitee requests. However, in construction mjury 
the subcontractor-employer's general liability carrier into the suit as well. Thus, there are two defendants; both inust fully defend the same claim while at the same time litigating the indemnity issue between themselves. The situation gets even more complex and more expensive when the employer's workers' compensation carrier, often different from his general hability carrier, enters the litigation to enforce a subrogation lien agamst the employee's recovery. ${ }^{33}$

Armco Steel Corp. v. Roy H. Cox Co. ${ }^{34}$ illustrates the inefficiency involved. The plaimtiff-employee prevailed at trial in 1974. The injury was compensated, and the goal of the tort system was, in theory, achieved. However, it was not until 1980, after more than six years of additional litigation, that the insurance companies finally resolved the question of who must pay what amount under the indemnity clause. A system which exists to compensate injured parties could make more efficient use of its resources. ${ }^{35}$

\section{III \\ The Federal Approach}

In the maritime area, where workers are protected by the Federal Longshoremen's and Harbor Workers' Compensation Act, ${ }^{36}$ similar indemnification problems have been reduced by congressional action.

\section{A. Indemnification Under the Federal Longshoremen's and Harbor Workers' Compensation Act}

Traditionally, longshoremen who were injured on a vessel could sue the vessel owners only on a negligence theory. In 1946, the Supreme Court extended the vessel owner's duty to longshoremen by holding that owners had a duty to maintain the ship in a seaworthy condition. ${ }^{37}$ In effect, this standard imposed strict liability on the vessel owner for imjuries to longshoremen. ${ }^{38}$ Subsequently, in Ryan Stevedoring Co. v. Pan-Atlantic S.S. Corp., the Supreme Court held that a vessel owner found liable under this standard was entitled to mdemnity,

litigation the obligation under the indemnity clause depends on the outcome of the litigation process, necessitating a full defense by the general contractor on his own behalf.

33. See, e.g., Associated Constr. \& Eng'g Co. v. Workers' Comp. Appeals Bd., 22 Cal. 3d 829, 842, 587 P.2d 684, 692, 150 Cal. Rptr. 888, 896 (1978).

34. 103 Cal. App. 3d 929, 163 Cal. Rptr. 330 (2d Dist. 1980).

35. For a review of the vast resources required for construction litigation, see L. HousE \& G. Smith, Construction Contract Litigation 51-55, 75 (1980).

36. 33 U.S.C. $\$ \S 901-950$ (1976 \& Supp. IV 1980).

37. Seas Shipping Co. v. Sieracki, 328 U.S. 85,99 (1946).

38. Id. at 93-94; Cohen \& Dougherty, The 1972 Amendments to the Longshoremen's and Harbor Workers' Compensation Act: An Opportunity for Equilable Uniformity in Tripartite Industrial Accident Litigation, 19 N.Y.L.F. 587, 589 (1974). 
either equitable or contractual, from the employer of the injured longshoreman. ${ }^{39}$ These two Supreme Court decisions created a situation like that involving California construction contracts: ${ }^{40}$ the employer paid the full tort damages for its employee's injury, despite the existence of a workers' compensation system designed to limit the employer's hability.

Congressional investigation revealed many of the probleins which California now faces in the construction industry. Congress was concerned with the madequacy of the benefits for mjured longshoreinen ${ }^{41}$ as well as with the indemnity problem. It recognized the drainatic increase in employee tort actions, and the corresponding increase in employer liability. ${ }^{42}$ Moreover, it recognized that money spent to administer such a systein could be better spent to pay for einployee injuries. ${ }^{43}$ Furthermore, although statutory benefits had not been increased for eleven years and the number of injuries had decreased, the cost of employer insurance had increased greatly because of these administrative costs and the increased hability of enployers. ${ }^{44}$

\section{B. The Congressional Response}

In response to these problems, Congress not only imcreased the statutory benefits available to mjured longshorenen, ${ }^{45}$ but also relieved vessel owners of the broad liability to which they were exposed. ${ }^{46}$ Most important, Congress enacted section 905(b) of the Longshoremen's and Harbor Worker's Compensation Act, which absolutely limits the einployer's liability to that imposed by the compensation statute by prohibitimg any claim for indemnity from the employer, whether in contract or in tort. ${ }^{47}$ In abolishing such indemnity claims, Congress reasoned that "[u]nless such hold-harmless, indemnity or contribution agreements are prohibited as a matter of public policy, vessels by their superior economic strengtll could circumvent and nullify the provisions of Section 5 of the Act [establishing the statutory benefits as absolute and maximum liability for einployers] by requiring indemnification from a covered einployer for einployee injuries." 48

39. 350 U.S. 124,125 (1956).

40. See supra text accompanying notes 23-33.

41. H.R. ReP. No. 1441, 92d Cong., 2d Sess. 1, reprinted in 1972 U.S. CODE CONG. \& AD. News 4698, 4698-99.

42. Id. at 5, 1972 U.S. CODE CONG. \& AD. News at 4702.

43. Id.

44. Id.

45. Id. at 1, 2-4, 1972 U.S. CODE Cong. \& AD. News at 4699, 4700-01.

46. Id. at 5-6, 1972 U.S. CODE CONG. \& AD. News at 4703.

47. Id. at 7, 1972 U.S. CODE CONG. \& AD. NEws at 4704; 33 U.S.C. $\$ 905(b)$ (1976).

48. H.R. REP. No. 1441, $92 \mathrm{~d}$ Cong., 2d Sess. at 7, reprinted in 1972 U.S. CODE CoNG. \& AD. NEWS at 4704. 
Similar considerations in employee suits against third-party indemnitees ${ }^{49}$ should lead to similar legislative action in California. The remainder of this Cominent proposes a systein for solving the problem.

IV

A Proposed Solution

A. Prior Legislative Responses

San Francisco Unified School District v. California Building Maintenance Co. ${ }^{50}$ was the first California case to assess the exclusivity of workers' compensation hability in light of a third party's clain for equitable indemnification based on an alleged breach of contract by the employer. After discussing the conflicts between the statutory scheme and the tort system, the California court relied on the United States Supreine Court reasoning in the Ryan case $^{51}$ and upheld the claim for indemnification. ${ }^{52}$ Thus, the California approach to the indeninity problem is directly based on reasoning which the United States Congress has rejected as leading to an unacceptable result..$^{53}$

The California Legislature was also dissatisfied with the result under the California Building Maintenance Co. approach. In response, it enacted Labor Code section 3864. ${ }^{54}$ That section provides that, in einployee suits agamst third parties, "the enployer shall have no liability to reimburse or hold such third person harniless on such judgment or settlement in absence of a written agreement so to do executed prior to the injury." 55 This section has been recognized in a few decisions as an attempt by the legislature to eliminate the dual insurance burden imposed upon employers by the operation of the equitable indemnity doctrine, ${ }^{56}$ which allowed indemnification even without a contractual agreeinent and thereby required the einployer to obtain insurance against the risk. However, as long as the statute continues to allow contractual indemnity agreeinents, it neither guarantees exclusivity of

49. See supra text accompanying notes 23-33.

50. 162 Cal. App. 2d 434, 328 P.2d 785 (1st Dist. 1958).

51. See supra note 39 .

52. 162 Cal. App. 2d at 447-49, 328 P.2d at 793-94.

53. See supra text accompanying notes $36-48$.

54. See Fleming, Report to the Joint Committee of the California Legislature on Tort Liability on the Problems Associated with American Motorcycle Association v. Superior Court, 30 HaSTings L.J. 1464, 1502 n.153 (1979). See also Gonzales v. R.J. Novick Constr. Co., 20 Cal. 3d 798, 807-08, 575 P.2d 1190, 1196, 144 Cal. Rptr. 408, 414 (1978).

55. Cal. Lab. Code $\$ 3864$ (West 1971).

56. See Herman Christensen \& Sons, Inc. v. Paris Plastering Co., 61 Cal. App. 3d 237, 243, 132 Cal. Rptr. 81, 89 (1st Dist. 1976); see also E.B. Wills Co. v. Superior Court, 56 Cal. App. 3d 650, 654-55, 128 Cal. Rptr. 541, 544 (5th Dist. 1976) (\$3864 "fully embraces the "exclusive remedy' concept visualized by the workers' compensation law of this state"). 
liability nor reduces the insurance burden. ${ }^{57}$

\section{B. Indemnity Clause Bargaining: An Illusion}

In creating section 3864 but limiting its scope so as not to prohibit express contractual indemnity, the California Legislature reasoned that although employer hability should be limited, considerations of contractual freedoin dictated that if an employer engages in arms-length bargaining and contracts to relinquish his limited liability under the workers' compensation system, the agreement should be enforced. ${ }^{58}$ However correct the legislature's approach may be in other situations, its reasoning does not adequately justify enforcing contractual indemmity provisions in the typical construction contract.

In the majority of construction contracts, as in the typical longshoreman's contract, ${ }^{59}$ there is nothing resembling arms-length bargaining or agreement over the indemnity clause. Rather, the clause is typically imposed upon the independent contractor in boilerplate language. The independent contractor either accepts the terms demanded by the general contractor or does not work, ${ }^{60}$ for the market is dominated by general contractors demanding such protection.

Confronted with a similar conflict between contractual freedoin in a comnercial setting and limits on such freedorn based upon public policy considerations, the California Supreme Court recently recognized that pubhic policy may prevail. In Graham v. Scissor-Tail, Inc., ${ }^{61}$ the plaintiff, Bill Graham, was an experienced concert promoter who entered into a contract with the defendants, musicians, for concert performances. The parties used the standard contract required by the inusicians' umion.

The suit involved a standard contract provision requiring that all disputes be resolved by arbitration before a union arbitrator. Despite Graham's prominence in his field, ${ }^{62}$ the negotiability of other terms of the contract, ${ }^{63}$ and the comniercial setting of the transaction, the court recognized that, since nearly all musicians use the standard contract, Graham was in a take-it-or-leave-it situation, and that the contract was an unconscionable and unenforceable contract of adhesion. ${ }^{64}$ Thus,

57. See supra text accompanying notes 23-33. Express or contractual indemnity is created by agreement between the parties, while implied or equitable indemnity arises by operation of law.

58. See Rossinoor Sanitation, Inc. v. Pylon, Inc., 13 Cal. 3d 622, 633, 532 P.2d 97, 104, 119 Cal. Rptr. 449, 456 (1975).

59. See supra text accompanying note 48 .

60. J. SwEET, supra note 22 , at 453-54.

61. 28 Cal. 3d 807, 623 P.2d 165, 171 Cal. Rptr. 604 (1981) (per curiam).

62. Id. at 812, 818-19, 623 P.2d at 167, 171-72, 171 Cal. Rptr. at 606, 610-11.

63. Id. at $819,623 \mathrm{P} .2 \mathrm{~d}$ at $172,171 \mathrm{Cal}$. Rptr. at 611 .

64. Id. at 818-19, 826, 623 P.2d at 171-72, 177, 171 Cal. Rptr. at 610-11, 616. 
the court recognized that even in coinmercial settings involving sophisticated and powerful parties, the circumstances may result in an unenforceable adhesion contract.

While such reasoning could apply to a wide range of contractual settings, ${ }^{65}$ it is particularly applicable to the typical construction contract. Courts have extended adhesion theory to the contracts between general contractors and subcontractors, ${ }^{66}$ and have demonstrated some concern over the lack of true bargaining in the typical construction contract process. ${ }^{67}$

Perhaps most indicative of the lack of any arms-length bargaining over indemnity provisions is the noticeable absence of cases in which a general contractor has agreed to indemnify an independent contractor for liability arising out of the performance of a construction contract. Rather, indemnity protection for the general contractor is the norm. ${ }^{68}$

The legislature has recognized the general contractor's ability to demand indemnity protection from the independent subcontractor and has responded in part by enactimg Civil Code section 2782.69 That section applies only to construction contracts and provides that terms which purport to indemnify a party against its own sole negligence or willful misconduct are "against public policy and are void and unenforceable. . . ."70

\section{Eliminating Indemnification}

Since there is generally no bargamed-for agreement to provide indemnity im construction contracts, freedom to contract cannot justify excluding contractual agreements from the scope of Labor Code section 3864. ${ }^{71}$ Following the example of section 905(b) the Longshoremen's and Harbor Workers' Compensation Act, ${ }^{72}$ section 3864 should be expanded to prevent any potential for indemnification, either in tort or in contract.

65. But see Note, Graham v. Scissor-Tail, Inc.: Unconscionability of Presumptively Biased Arbitration Clauses Within Adhesion Contracts, 70 CALIF. L. REv. 1014, 1031-34 (1982) (criticizing Scissor-Tail and arguing for its limited application).

66. See Player v. George M. Brewster \& Son, Inc., 18 Cal. App. 3d 526, 536, 96 Cal. Rptr. 149, 156 (3d Dist. 1971).

67. See Castro v. State, 114 Cal. App. 3d 503, 510, 170 Cal. Rptr. 734, 737 (4th Dist. 1981).

68. See J. SweET, supra note 22, at 750.

69. CAL. CIV. CODE $\S 2782$ (West 1974); see supra text accompanying note 25.

70. Cal. Civ. Code $\$ 2782$ (West Supp. 1981).

71. The existence of a bargained-for exchange is the typical justification for upholding indemnity clauses. See John E. Branagh \& Sons v. Witcosky, 242 Cal. App. 2d 835, 843-44, 51 Cal. Rptr. 844, 850 (1st Dist. 1966).

72. See supra text accompanying notes $36-48$. 


\section{Adopting the Federal Approach}

Several California cases have come close to following the federal approach and prohibiting indemnification. ${ }^{73}$ The court of appeal has recognized that allowing indemnification when the general contractor is at all neghigent nnay be against public policy, and that Civil Code section 2782 could justifiably be expanded to prevent indemnification under such circunstances. ${ }^{74}$ An expansion of Civil Code section 2782 would have essentially the same effect as the expansion of Labor Code section 3864 proposed in this Comnient: it would prevent indemnification in all cases in which the general contractor is liable. Also, in the first case upholding the constitutionality of Labor Code section 3864, the court of appeal indicated that the goals of the compensation system not only justified but perhaps required limiting the liability of einployers to such third parties. ${ }^{75}$ Thus, section 3864 was an initial step in the right direction; however, its scope must be expanded in order to accomphish fully its purpose.

\section{Effects of Abolishing Indemnification}

Prohibiting indemnification will not only help achieve the purposes of section 3864 and the compensation system in general; it will also lead to a more efficient, less expensive system for coinpensating employees for their injuries. To the extent general contractors are made more directly responsible for their own negligence, they will have a stronger incentive to promote jobsite safety, and the number of employee injuries may be reduced. ${ }^{76}$ Furtherniore, the need for inultiple insurance against the same risk will be eliminated, and costs will accordingly be reduced. By removing one liability issue and one insurance company from the hitigation or settlement process, the cost and complexity of the claim process will also be lessened.

Finally, prohibiting indemnification of the general contractor will alleviate the problems associated with a halfhearted defense by third parties. Under the current California system, the third-party general contractor is in inost cases merely a nominal defendant with nothing significant at risk, since it will be fully reinubursed for any liability it may incur. ${ }^{77}$ Therefore, the employer's interests may be inadequately represented, resulting in increased recoveries for plaintiff-employees.

73. See, e.g., supra text accompanying notes 7 \& 10.

74. See Armco Steel Corp. v. Roy H. Cox Co., Inc., 103 Cal. App. 3d 929, 934, 163 Cal. Rptr. 330, 333 (2d Dist. 1980).

75. Alameda Tank Co. v. Starkist Foods, Inc., 103 Cal. App. 3d 428, 432-33, 162 Cal. Rptr. 924, 926-27 (2d Dist. 1980).

76. See generally W. Prosser, supra note 30, at 23.

77. See supra notes 68-69 and accompanying text (describing situations in which a generaI contractor will not be protected by an indemnity clause). 
The employer may of course attempt to take a nore active role in the litigation. However, this too results in an additional and unnecessary expenditure of the subcontractor-employer's resources. Only an absolute prohibition of indemnity provisions in construction contracts would permit the subcontractor to benefit from the limitation on liability under the workers' compensation system.

\section{Limiting Third-Party Liability to Comparative Fault}

If, in accordance with the above proposal, the employer's liability is limited to that provided in the workers' compensation statutes when the plaintiff is an injured employee, the third-party defendant's liabihity should be limited to that portion of the einployee's damages for which the third party is responsible. A system of comparative fault liability should be applied to the third party, but the employer's workers' compensation shield should not result in the third party bearing the burden of joint and several liability normally associated with comparative fault principles.

\section{Justification for Joint and Several Liability}

When comparative fault principles were first considered, many comnentators proposed limitimg each defendant's liability to its proportional responsibility for the injury. ${ }^{78}$ However, when the issue first came before the California Supreme Court, the court held that although comparative fault principles were to be applied, defendants were still to be held jointly and severally hable for the total damages of the plaintiff. ${ }^{79}$ The court reasoned that where a defendant is immune froin suit or is unable to pay its full share of the damages, it is better that a concurrently neghigent defendant bear an additional burden than that a plaintiff should suffer a dimimished recovery. ${ }^{80}$

Applying this reasoning to an employee suit against a third party, the California Court of Appeal expressed concern over the inequity inherent in holding the third party liable for the full amount of the damages when workers' compensation prevented him from seeking contribution froin a concurrently neghigent employer. Nevertheless, the court held that the third party was subject to joint and several lia-

78. See, e.g., the discussion and authorities cited in Fleming, supra note 54, at 1494-98; Commeut, Comparative Negligence, Multiple Parties, and Settlements, 65 CALIF. L. Rev. 1264, 1285 (1977).

79. American Motorcycle Ass'n v. Superior Court, 20 Cal. 3d 578, 586, 578 P.2d 899, 903, 146 Cal. Rptr. 182, 186 (1978).

80. Id. at 586-90, 578 P.2d at 903-07, $146 \mathrm{Cal}$. Rptr. at 186-90. But cf. Davis, Third-Party Tortfeasors' Rights Where Compensation Covered-Employers are Negligent-Where do Dole and Sunspan Lead?, 3 WORKMEN's COMP. L. REv. 1, 7 (1976) (criticizing the requirement that the third-party tortfeasor must compensate for the employer's negligence). 
bility for the plaintiff's injury, ${ }^{81}$ and as a result the third party was effectively held liable for harm actually caused by the einployer's negligence.

\section{Failure of the Justification in the Construction Setting}

The factors justifying joint and several liability in the typical tort suit, however, are not present in the unique workers' compensation setting: the codefendant-eniployer is not insolvent, immune, or a settling party.

First, when the plaintiff lias received workers' coinpensation benefits, any analogy between tlie eniployer and an insolvent tortfeasor is misplaced. Insolvency implies the inability of a defendant to satisfy its obligation to the plaintiff. ${ }^{82}$ Under the workers' compensation systen, however, the eniployer's solvency is secured by insurance covering the risk of an einployee's injury. ${ }^{83}$ Thus, the statutory benefits are paid by the einployer's insurer, and there is no additional obligation of the enployer for the third party defendant to satisfy.

Second, the iminunity justification for joint and several liability is inapplicable when workers' compensation is available. Immunity implies that the plaintiff is unable to inake a negligent party answer for the liarm to which it has contributed. ${ }^{84}$ Under the workers' coinpensation system, the employer is only "immune" from additional contribution to the third party; the employer is not immune front liability to the enployee for his loss.

Finally, the relationship between the general contractor and the subcontractor is not analogous to that between a non-settling and a settling defendant. A plaintiff who settles exchanges speculative rights for the benefit of a certain recovery; a defendant who settles exclianges a possible but perhaps reinote chance of exculpation for a certain but limited liability. ${ }^{85}$ The remaining defendants beconie liable for the full amount of the dainages less only the amount of the settleinent, even if such amount exceeds their coniparative liability. ${ }^{86}$ Such a systein en-

81. Arbaugh v. Procter \& Gamble Mfg. Co., 80 Cal. App. 3d 500, 505-07, 145 Cal. Rptr. 608, 613 (2d Dist. 1978).

82. See CAL. CoM. Code $\S 1201$ (23) (West Supp. 1982).

83. Private employers may secure the payment of workers' compensation benefits to their employees by purchasing insurance, see CAL. LAB. CODE $\S 3700$ (a) (West Supp. 1982), or by selfinsuring, see id. $\S 3700$ (b), which requires depositing cash, securities, or a surety bond with the State Director of Industrial Relations, see id. § 3701. See also id. $\S \S 3700.5,3702.3,3706-3709.5$ (describing penalties for failure to secure compensation adequately), and $\$ \S 3710-3732$ (establishing an unimsured employers' fund).

84. W. Prosser, supra note 30 , at 970.

85. L. House \& G. Smith, Construction Contract Litigation $51-55$ (1980).

86. When a defendant settles, the liability of the non-settling defendants is diminished only by the amount of the settleinent, not by the proportional liability of the settling defendant for the 
courages settlement by rewarding the settling defendant with limited liability while increasing the potential liability of the non-settling defendant.

No similar considerations justify liability beyond comparative fault when a plaintiff receives workers' compensation from a concurrently neghigent tortfeasor. The plaintiff and employer have not exchanged speculative rights; nor do they need encouragement to settle. The employer and einployee know their respective obligations and rights to a statutory certainty. Moreover, the threat of increased exposure will not influence the third party's mclination to settle. Although a settlement will also establish with certainty the extent of its liability, it is not faced with increased liability should a codefendant settle. Rather, the employer and employee have with finality reaclied an acceptable allocation of liability in the form of workers' compensation benefits. The third party's potential liability is thus defined, and the imposition of joint and several liability will not be a factor influencing the third party to settle.

Rather than justifying joimt and several liability, the factors present im employee suits against third parties support limiting third-party liability to the third party's coinparative fault. ${ }^{87}$ Limiting third-party liability to the extent of comparative fault may itself facilitate settlement. As the amount at stake is diminished, it becomes increasingly likely that the parties can reach an agreement on the value of a settlement. Moreover, limiting third-party fault removes several intangibles from the calculation of the settleinent value, ${ }^{88}$ simplifying the calcula-

total tort damages. See CAL. Civ. Proc. CODE $\S 877$ (West 1980). Thus, a non-settling defendant, like a codefendant of an immune or insolvent tortfeasor, is exposed to potential liability beyond its comparative fault. But see Baget v. Shepard, 180 Cal. Rptr. 396 (4th Dist. 1982), officially depublished pursuant to CAL. R. CT. 976(d) (West 1976) (reducing the nonsettling defendant's liability by the full comparative liabihty of the settling defendant, thereby limiting the nonsettling defendant's liabiity to its comparative fault).

87. Despite the exclusive aspect of the workers' compensation remedy against the employer, a few courts have permitted third parties to recover froun the employer an amount equal to the employer's share of fault. See, e.g., Skinner v. Reed-Prentice Div. Package Mach. Co., 70 Ill. 2d 1, 14-16, 374 N.E.2d 437, 443 (1977), cert. denied, 436 U.S. 946 (1978); Dole v. Dow Chen. Co., 30 N.Y.2d 143, 152-53, 282 N.E.2d 288, 295, 331 N.Y.S.2d 382, 390-91 (1972).

At least one other court has recognized that though the exclusivity of the workers' coinpensation statute prevents employer contribution, the third party's liability should nonetheless be limited to that party's comparative fault. See Barron v. United States, 473 F. Supp. 1077, 1085 (D. Hawaii 1979), modified, 654 F.2d 644 (9th Cir. 1981). The suggestion that a third party's liability should be limited to that party's comparative fault is therefore not new. See, e.g., Tarpley \& Jagmin, supra note 5, at 214-24.

88. For example, with joint and several liability, third parties must consider the chance that other defendants inay settle or be insolvent and that their potential liability may thus be expanded if a judgment were rendered against thein. Thus, the settlement value of the clain may include risk aversion factors and gambling tactics by the parties, rather than focusing narrowly on the liability of the individual defendant. 
tion to damages times the comparative fault of the third party.

Under the comparative fault system, joint and several liability operates to alleviate the inequitable results produced by unusual circumstances, such as the immunity or insolvency of one of a group of defendants. ${ }^{89}$ However, in third-party suits in which the plaintiff receives workers' compensation, such coinpensation has already ensured that the employee is not the victim of any misfortune. The plaintiff is the beneficiary not only of a guaranteed recovery but also of the good fortune of having an additional party from whoin lie or she can recover. ${ }^{90}$ In such situations, it is the third party who may properly be viewed as a victim of misfortune, since it will suffer a loss as a result of the employer's immunity from contribution. Therefore, it is the third party who needs the benefit of hability limited to its comparative fault.

\section{Restricted Application of Limited Third-Party Liability}

The proposed limitations on liability can properly be restricted to cases in which the third-party defendant is a party to the enterprise which the plaintiff-employee was serving when injured. That is, only defendants who are involved in the operation and implementation of the construction project need be protected by hability limited to their comparative fault. This group would of course include general contractors and property owners-both of whoin might hire subcontractors-and could mclude other subcontractors on the project as well.

This narrow application of the limited hability principle is proper for several reasons. First, although the employee inay be viewed as having accepted the quid pro quo of guaranteed recovery through the workers' compensation system, the scope of this arrangement should be limited to those injuries closely connected with the perfornance of the job. When the employee is injured in the ordinary course of employment through the negligence of a general contractor or its agent, the injury is sufficiently tied to norinal job risks to fall within the contemplated scope of the workers' compensation systern of limited but certain recovery. However, there is no reason to believe that an employee ever intended to agree to a limited recovery when, for exainple, he is injured on the jobsite by a neghigent autonobile driver not involved with the job. ${ }^{91}$

Second, problems arise from employee suits because the parties

89. American Motorcycle Ass'n v. Superior Court, 20 Cal. 3d 578, 586-90, 578 P.2d 899, 90307, 146 Cal. Rptr. 182, 186-90 (1978).

90. See generally Edmonds v. Compagnie Generale Transatlantique, 443 U.S. 256, 273-80 (1979) (Blackmun, J., dissenting) (guarantee of statutory benefits plus risk-free chance at tort recovery called inequitable).

91. See, e.g., Mello v. Cooperheat, Inc., No. 174969 (Cal. Contra Costa County Super. Ct. Apr. 4, 1980), summarized in 24 JURY Verdicts WeEKLY, May 16, 1980, at 4. 
involved in the construction project pursue conflicting individual interests while the goal should be to inake sure injured einployees are coinpensated at a minimum cost to the construction enterprise as a whole. ${ }^{92}$ The current method of allocating the loss annong the parties results in inefficiency to the enterprise, which is the crux of the problein; the solution must provide a inore efficient and equitable allocation of costs among these parties. Thus, the limited liability principle is properly addressed only to those parties involved in the construction project.

Third, when the workers' compensation system was conceived, few jobsites had as many potential third-party defendants as do typical modern construction projects. ${ }^{93}$ The problem of loss allocation has arisen as a result of the increased use of imdependent contractors; it is only this narrowly defined conflict between competing interests which must be resolved.

Finally, the frequency of einployee suits against third parties who are involved in the construction enterprise indicates the need as well as the justification for legislative action aimed particularly at solving loss allocation problems in this area.

\section{Compensation Results Under Limited Liability: A Fair Balance}

Because the employer's liability is limited under workers' compensation, the loss must be allocated other than through a directly proportional sharing of the liability. Any solution will necessarily require a compromise between conflicting interests. In resolving this conflict, the employee's interests vis-a-vis the employer must be viewed as satisfied when the statutory benefits have been paid. The third party's liability must then be limited to its comparative fault. ${ }^{94}$ Although the injured party inay not receive full tort compensation in all cases, the employee will always receive a recovery fully consistent with the workers' compensation system. Such a recovery is not unjust, but is both fair and adequate.

\section{E. Eliminating Subrogation Liens}

Once indemnity coverage is eliminated and third-party liability is limited to the extent of comparative fault, the loss allocation system can

92. J. SWEET, supra note 22, at 753-54. In a majority of the states a general contractor is treated as an employer of a subcontractor's employee, and is liable to the employee only to the extent of the statutory benefits. See A. LARSON, WorkmeN's Compensation LaW \& 72.31(a) (1976).

93. Interview with John G. Fleming, Professor of Law, Boalt Hall School of Law, in Berkeley, California (Feb. 8, 1982).

94. This suggestion means that an employee's recovery due to employer negligence is necessarily limited to workers' compensation benefits. Such a result is in accord with the purpose of the system. See supra notes 8-10 and accompanying text. 
be further streamlined. This Section proposes eliminating any lien that the einployer or its insurance carrier, seeking to obtain reimburseinent for workers' compensation benefits paid, might mipose on the einployee's tort recovery.

\section{The Present Lien System}

Under the current systein, the rule is that the concurrently neghgent employer should receive either credit or reimbursement for the amount by which its coinpensation liability exceeds its proportional share of the injured einployee's recovery. ${ }^{95}$ Under this system, the einployer ${ }^{96}$ receives a lien against the employee's tort recovery. It can enforce this hen in several ways, including bringing a separate suit. ${ }^{97}$ No matter how the lien is enforced, however, pursuit of the lien recovery not only results in its own adininistrative expenses, such as attorney fees for the parties and the accoinpanying expenditure of judicial resources, but inay also yield a net loss to the lienholder-enployer itself if the cost of enforcing the hen exceeds the ainount recovered.

\section{Shortcomings of the Present System}

The employer's recovery under its subrogation lien is partly dependent on the einployer's coinparative fault. ${ }^{98}$ The einployer's lien on

95. Associated Constr. \& Eng'g Co. v. Workers' Comp. Appeals Bd., 22 Cal. 3d 829, 842, 587 P.2d 684, 692, 150 Cal. Rptr. 888, 896 (1978).

96. CAL. LAB. CODE $\S \S 3850,3852-3862$ (West $1971 \&$ Supp. 1982) establisl the reimbursement rights of the employer. Section 3850 provides that with respect to reimbursement, "employer" is defined to include a workers' compensation insurer. In most situations, it is actually an imsurer who is seeking to enforce the hen. Lasky, Subrogation Under the Workmen's Compensation Laws-Rules, Remedies and Side Effects, 12 SanTa Clara Law. 1, 2 (1972). As used in this Comment, "employer" imcludes an insurer as a subrogated lienholder.

97. See Witt v. Jackson, 57 Cal. 2d 57, 69, 366 P.2d 641, 648, 17 Cal. Rptr. 369, 376 (1961); CAL. LAB. CODE $\S 3856$ (West 1971). The employer might also intervene in an action brouglit by the employee, or allow the employee to prosecute the action limself and subsequently seek a hen against the employee's recovery.

98. The employer recovers on the lien only to the extent the workers' compensation benefits paid to the employee exceed the amount of the employee's total damages for which the employer would be liable but for the limited liability protection of the workers' compensation system. For example, if the employee receives a $\$ 50,000$ judgment and the employer las paid $\$ 10,000$ in compensation benefits, the lien recovery would vary according to the employer's negligence as follows:

$\begin{array}{lcc}\begin{array}{l}\text { Employer's } \\ \text { Comparative } \\ \text { Negligence }\end{array} & \begin{array}{c}\text { Employer's Liability } \\ \text { but for Workers' } \\ \text { Compensation Limitations }\end{array} & \begin{array}{c}\text { Value of } \\ \text { Lien Recovery }\end{array} \\ 0 \% & \$ 0 & \$ 10,000 \\ 5 \% & \$ 2500 & \$ 7500 \\ 10 \% & \$ 5000 & \$ 5000 \\ 20 \% \text { and above } & \$ 10,000 & \$ \quad 0\end{array}$

See, e.g., BAJI No. 15.14 (6th rev. ed. Supp. 1981) and the accompanying examples.

To further complicate matters, if the employee settles witls the third party, the lien must be valued by first determining the employee's actual damages without regard to the amount of the 
the employee's tort award is realized only when the amount paid to the employee in workers' compensation benefits exceeds the amount for which the employer would have been liable under ordinary coinparative fault but for the compensation shield. ${ }^{99}$ However, such determinations of comparative fault coine only as the result of court judgments; consequently, the lienholder-employer will have an interest in the litigation from beginning to end, despite the possibility of little or no recovery. ${ }^{100}$ This adds to the complexity and therefore to the cost of resolving the einployee's underlying claim: it injects into the litigation the employer, who would not be involved but for the lien, and whose interest and presence complicate the trial and inay confuse the jury. ${ }^{101}$ Moreover, the presence of a lienholder in the litigation may lead to decreased tort recoveries for injured employees, since the jury is squarely presented with the fact that the plaintiff-employee has received compensation from a collateral source. ${ }^{102}$

Soine liens are no doubt easy and profitable to enforce. In a inajority of the litigated cases, however, lien enforcement taxes the system as well as the lienholder, whose lien may be worth less than the cost of enforcement. ${ }^{103}$

The coinpensation lien also needlessly coinplicates settleinent negotiations, the method through which the vast majority of employee tort claims are resolved. ${ }^{104}$ In order to ensure that settlement fully ex-

settlement. For example, even if the employee settles for $\$ 50,000$, it may be determined that the actual damages are $\$ 100,000$. Next, the employer's comparative fault must be determined. The lien is then worth the excess of benefits paid over the employer's coinparative liability (but for the statutory limitation), for the full extent of the employee's actual damages. See Associated Constr. \& Eng'g Co. v. Workers' Comp. Appeals Bd., 22 Cal. 3d 829, 842-47 \& n.10, 587 P.2d 684, 692-95 \& n.10, 150 Cal. Rptr. 888, 896-99 \& n.10 (1978). Such determimations may be made by the Workers' Compensation Appeals Board when the plaimtiff and the third party settle before trial. Id.

99. See, e.g., Rodriguez v. McDonnell Douglas Corp., 87 Cal. App. 3d 626, 151 Cal. Rptr. 399 (2d Dist. 1978).

100. See Lasky, supra note 96, at 20. Lasky points out that when the employer wishes to defend agaimst the comparative fault allegations and thus maximize its hen recovery, it must intervene, since its imterests are often madequately protected by the employee. See also CaLIForNia Continuing education of the Bar, California Workmen's Compensation Practice $\S 17.21$ (M. Witt ed. 1973 \& Supp. 1982) [hereinafter cited as WorkMEN's CoMpenSATION PraCTICE]. Moreover, an employer will be encouraged to remain an active participant im order to assure that it lias the necessary bargaining power and imformation to obtain the most favorable recovery possible in the event of a settlement.

101. See BAJI No. 15.14 \& use note \& comment (6th ed. 1977 \& Supp. 1981).

102. To establish the value of its lien, the employer is entitled to offer as evidence the total amount of benefits paid to the einployee. See CAL. LAB. CoDE $\S 3855$ (West 1971); Mendenhall v. Curtis, 102 Cal. App. 3d 786, 789, 162 Cal. Rptr. 569, 571 (4th Dist. 1980); Smith v. County of Los Angeles, 276 Cal. App. 2d 156, 159-71, 81 Cal. Rptr. 120, 122-30 (2d Dist. 1969).

103. Telephone imterview with Alan Tebb, General Manager of the California Workers' Compensation Institute (Feb. 25, 1982).

104. See, e.g., ANnuAl Report, Judicial Council of CAlifornia 78 (1982) (In fiscal year 
tinguishes their hability, third-party defendants typically make their settlement offers contingent upon the plaintiffs agreement to satisfy the hen from the settleinent proceeds. ${ }^{105}$ Once such an agreement is reached, the liens are greatly compromised. ${ }^{106}$ After settlement, the henholder must look to the plaintiff-employee to satisfy the hen. Since the plaintiff will not be tryimg the case, the necessary finding of comparative fault will never be made, and the value of the lien will therefore be speculative. The lienholder may of course pursue the lien by bring$\mathrm{mg}$ an independent action, but it will be gambling on obtaining the necessary comparative fault determination. ${ }^{107}$

Thus, the lienholder's only opportunity for fully pursumg its lien is in most situations impractical. The lienholder is left witll little bargainmg power after a settleinent, and, as a result of pressure from plaintiff's counsel, the third-party defendant, and the presidimg judge, it will often accept a nominal settlement on the lien. ${ }^{108}$

In the typical settlement scenario, then, the lienholder incurs substantial expense as an interested party; by complicating the settlement process, it imposes increased expense on the other parties as well. Yet, this burden typically yields at best only a nominal recovery. As a result, the availability of the lien leads only to a waste of resources-a cost without a benefit.

Another justification offered for subrogation liens, in addition to their loss allocation effect, is that they provide an incentive for einployer safety. ${ }^{109}$ However, any safety incentive is insufficient to justify otherwise wasteful employer liens. ${ }^{10}$

A potential lien recovery could increase employer safety only if it had a direct impact upon the employer's insurance premiums. Of course, if, as argued above, the hens are not profitable for insurance companies to pursue, subrogation rights will in fact have no such effect on premiums. However, even if they are in fact nuargmally profitable for carriers, the existence of subrogation rights will not necessarily act as a safety imcentive for employers.

Insurance premiunis are based on averages, not on anonialies. ${ }^{11}$

1980-81, 94.9\% of all personal injury clains filed in the superior courts were settled, with only $2.8 \%$ going to contested trials.).

105. See Workmen's Compensation Practice, supra note $100, \S 17.18$ at 626.

106. See id. \& 17.17, at 625 .

107. I S. Herlick, California Worker's Compensation Law Handbook $\S 12.12$, at 426 (2d ed. 1978).

108. See Workmen's Compensation Practice, supra note 100, $\$ \S 17.7,17.17$, at 617, 625.

109. Lasky, supra note 96 , at 34.

110. Epstein, supra note 9, at 467 (1978). "[O]ne of the unfortunate effects of the workers" compensation law is that its relatively low benefit structure tends to encourage an underinvestment in safety by employers. . . ." Id.

111. Lasky, supra note 96, at 5-6. 
An employer with a consistently good safety record will be able to obtain insurance at a lower premium. ${ }^{112}$ Thus, even though they have limited hability under the workers' compensation system, employers have an incentive to promote workplace safety. On the other hand, since subrogation recoveries may actually have hitle or no effect on the premium an individual einployer pays, their safety incentive is likely to be minimal.

Workers' compensation imsurance premiums are effectively set by the California Inspection Rating Bureau. ${ }^{13}$ To set the rates, the bureau starts with the expected total accident cost, subtracts anticipated subrogation recoveries, and adds operating and administrative expenses to determine the amount which inust be collected in premiums. ${ }^{114}$ By thus focusing on gross subrogation recoveries rather than on net recoveries after excluding the cost of enforcing the hens, the bureau's inethod of calculation furthers the perception that liens reduce costs, reduce premiun1s, and result in significant safety incentives. ${ }^{115}$ To an extent, this may be true. However, when lien recoveries are reduced by the costs of enforcement, the actual impact of lien recoveries upon employer safety is significantly diminished, and the safety justification for the lien systein becoines inuch less convincing.

\section{The Advantages of Abolishing Liens}

As origmally conceived and intended, the workers' compensation system keeps the einployer out of the courtrooin when an einployee is mjured. ${ }^{116}$ However, even if indemnification is prohibited, subrogation hens have the unfortunate consequence of dragging the employer back into court. If liens are abohished, the employer will again be properly absent from the litigation process, settleinent and trial will be facilitated, and time and expense will be saved. ${ }^{117}$ The elimination of enployer's liens against workers' tort recoveries would thus further the pohicy behind the workers' coinpensation system.

Moreover, the elimination of subrogation liens is consistent with the quid pro quo concept of the coinpensation systein. ${ }^{118}$ As consideration for limited hability following employee injuries, employers have agreed to pay certain minimum benefits regardless of fault. An ein-

112. See id. at 6.

113. Id. at 5 .

114. Id.

115. Telephone interview with Alan Tebb, General Manager of the California Workers' Compensation Institute (Feb. 25, 1982).

116. See Epstein, supra note 9, at 472; Edmonds v. Compagnie Generale Transatlantique, 443 U.S. 256, 270-71 (1979).

117. Epstein, supra note 9, at 468.

118. For a discussion of the quid pro quo exchange, see supra text accoinpanying notes 5-10. 
ployer, whether negligent or careful, sliould not expect to receive a benefit in the form of a subrogation recovery because a third-party tortfeasor is involved. The employer receives the benefit of limited liability; it can fairly be expected to pay for that benefit with certainty of hability. ${ }^{119}$ Thus, it is both justifiable and desirable to eliminate subrogation liens, because the resulting savings outweigli the lost recoveries.

\section{CONCLUSION}

The workers' compensation and tort systems can only be reconciled by recognizing a common goal: to ensure adequate compensation for all injured einployees while minimizing tlie cost of providing such protection.

The system proposed in this Coinment ensures adequate recovery for all employees. Moreover, it furthers the purpose of the workers' compensation systein by limiting absolutely an einployer's liability to that imposed by the statutory scheme. Finally, the proposed systein preserves safety incentives by ensuring the liability of third parties for their own negligence.

Of course, under this system, employees will sometimes have to sacrifice full tort recoveries, employers will sometimes have to sacrifice their liens in exchange for truly limited liability, and third parties will sacrifice contractual indemnity in exchange for hability limited to coinparative fault. However, as this Comnient has demonstrated, the enforcement of these parties' rights perpetuates the conflict and the mefficiency in the current system of loss allocation. The proposed system eliminates these inefficiencies and furthers the primary purpose of both workers' compensation and the tort systein by ensuring that the legitimate needs of all parties are satisfied. It thus represents a vast improvement over the present systein of loss allocation.

Mark C. Zebrowski*

119. Denying subrogation liens does present one problem: an employee may receive a recovery in excess of his actual loss. To avoid this possibility, third-party liability could be reduced by the anount necessary to prevent double recovery. See, e.g., Rodriguez v. McDonnell Douglas Corp., 87 Cal. App. 3d 626, 669, 151 Cal. Rptr. 399, 423 (2d Dist. 1978).

* B.B.A. 1979, University of Wisconsin-Madison; third-year student, Boalt Hall School of Law, University of California, Berkeley. 